ISSN 0868-854 (Print)

ISSN 2413-5984 (Online). Algologia. 2015, 25(4):420-427

http://dx.doi.org/10.15407/alg25.04.420

K. AISHA, M. SHAMEEL

Department of Botany, University of Karachi,

Karachi-75270, Pakistan

e-mail: draisha14@gmail.com

\title{
TAXONOMY OF THE GENUS IYENGARIA BØRGESEN (PHAEOPHYCOTA) FROM COASTAL WATERS OF KARACHI, PAKISTAN
}

\begin{abstract}
Globular, hollow and stellate thalli of the brown algal genus Iyengaria were collected from various coastal areas of Karachi and taxonomically investigated. This study revealed the presence of two species i.e. I. stellata (Børgesen) Børgesen and a new species, I. lobocylindrica Aisha et Shameel. The new species is characterized by the thin walled thallus, hollow projections, cortex not differentiated into inner and outer portion, absence of phaeophycotaen hairs, and thin walled plurilocular sporangia with rectangular locules. Its thalli are lobed in early stages but gradually become cylindrical.
\end{abstract}

Ke y words: algae, Phaeophycota, Iyengaria, taxonomy, morphology, anatomy, reproduction.

\section{Introduction}

Iyengaria is a genus of brown algae (family Scytosiphonaceae, order Scytosiphonales, class Laminarophyceae, Phaeophycota). It commonly grows in the coastal waters of the northern Arabian Sea, Wherefrom it was described for the first time by Børgesen as an independent genus, No doubt, it was taxonomically described from the coast Karachi and was also reported to occur in other coastal areas of Pakistan, but no detailed taxonomically study was carried out. Therefore, a large collection survey of this genus was made from various areas of Karachi coast at the present study was undertaken.

\section{Materials and Methods}

Algal thalli were detached from the rocks at mid and lower littoral zones from the coast of Karachi. They were brought to the laboratory and preserved in $4 \%$ formaldehyde. Different parts of thalli were cut into thin slices with the help of shaving blade by free hand section cutting technique. Sections were stained in $1 \%$ aniline blue for 5-10 min, one or two drops of $1 \mathrm{M}$ hydrochloric acid were added for 30 seconds and washed with seawater. The sections were then mounted in a solution of $75 \%$ glycerin with aniline blue ( $75 \mathrm{~mL}$ Gly $+20 \mathrm{~mL}$ aniline blue $+5 \mathrm{~mL}$ distilled water). Finally the slides were sealed with the sealing material (Cutex) and observed under microscope (Nikon, Japan).

(C) K. Aisha \& M. Shamel, 2015 


\section{Results and Discussion}

The specimens of Iyengaria Børgesen 1939:91, collected from various coastal areas of Karachi, were taxonomically investigated. They revealed the following characters of the genus. Thallus globular, hollow, stellate; attached by its lower surface; projections present, hollow as well as solid, have di- or trichotomous apex, which gives stellate appearance to the thallus, brown to dark brown in colour; internally five to six layers thick, peripheral region having small squarish cells; cortical part with rectangular to squarish cells and sometimes cells irregular and medullary part hollow; phaeophycotean hairs present, singly or in groups; growth intercalary or trichothallic; plurilocular sporangia cylindrical to clavate commonly uniseriate, rarely biseriate; paraphyses absent; sporangia formed in sori, distributed on thallus surface. Two species were found to grow at the coast of Karachi, which may be distinguished as given below:

1. Projections hollow throughout Iyengaria lobocylindrica (1)

Projections not hollow throughout Iyengaria stellata (2)

1. Iyengaria lobocylindrica sp. nov. Figs. 1, 2, $a-c$

Diagnosis. Cavus projecturia, pilis et paraphyses phaeophycoteanis absentia, corticatus non differentia in interiore et exteriore corticatus, sporangia plurilocularis tenuis paries rectangularibus loculi.

\section{Morphological characters}

Thallus light to yellowish brown, rounded to oval, $3.0-9.5 \mathrm{~cm}$ in diameter, crispy; attached to substratum by septate rhizoidal filaments; bearing cylindrical projections, up to $5 \mathrm{~mm}$ long, $2 \mathrm{~mm}$ in diameter; thalli in early stages lobed, gradually becoming cylindrical, apices round and thick.

\section{Cytological features}

Thallus composed of five to six layers of cells, distinguished into peripheral layer, cortex and central cavity; single layer of peripheral cells rectangular to squarish, transversely as well as longitudinally arranged with dense phaeoplasts, 6-9 $\mu \mathrm{m}$ long (3-) 6-9 $\mu \mathrm{m}$ broad; no differentiation of outer and inner cortex, cortical cells angular to irregular, 22-80 $(-108) \mu \mathrm{m}$ in length, 25-102 $(-185) \mu \mathrm{m}$ in width; phaeophycotean hairs not observed.

\section{Reproductive structures}

Sori scattered on the surface bearing cylindrical to clavate, plurilocular sporangia, covered by cuticle, uniseriate to biseriate, (9-) $22-31 \mu \mathrm{m}$ in length, (3-) 6-9 $\mu \mathrm{m}$ in breadth; 4-12 locules, more or less rectangular in shape; unilocular sporangia were not recorded, paraphyses absent.

Growth: The growth is diffuse.

Type locality: Buleji, Karachi, Pakistan.

Habitat ecology: Thallus epilithic, grows on rocky platform exposed to low tidal conditions. It was found growing in association with Iyengaria stellata, Colpomenia sinuosa (Mert. ex Roth) Derbès et Solier and Lobophora variegata (Lamour.) Womer. ex Oliveira. 


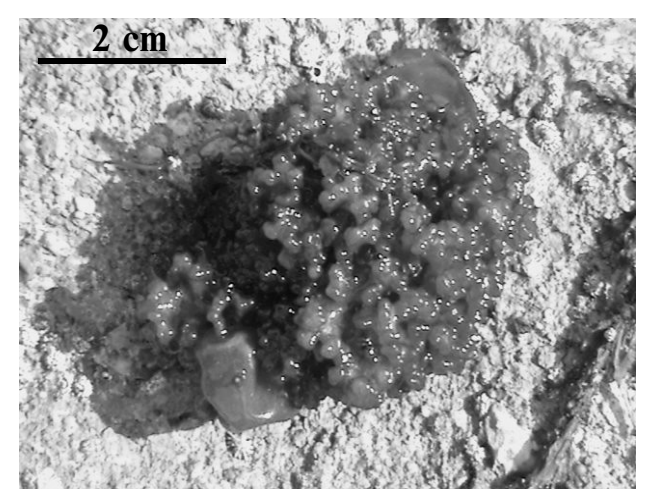

Fig. 1. Iyengaria lobocylindrica: type specimen

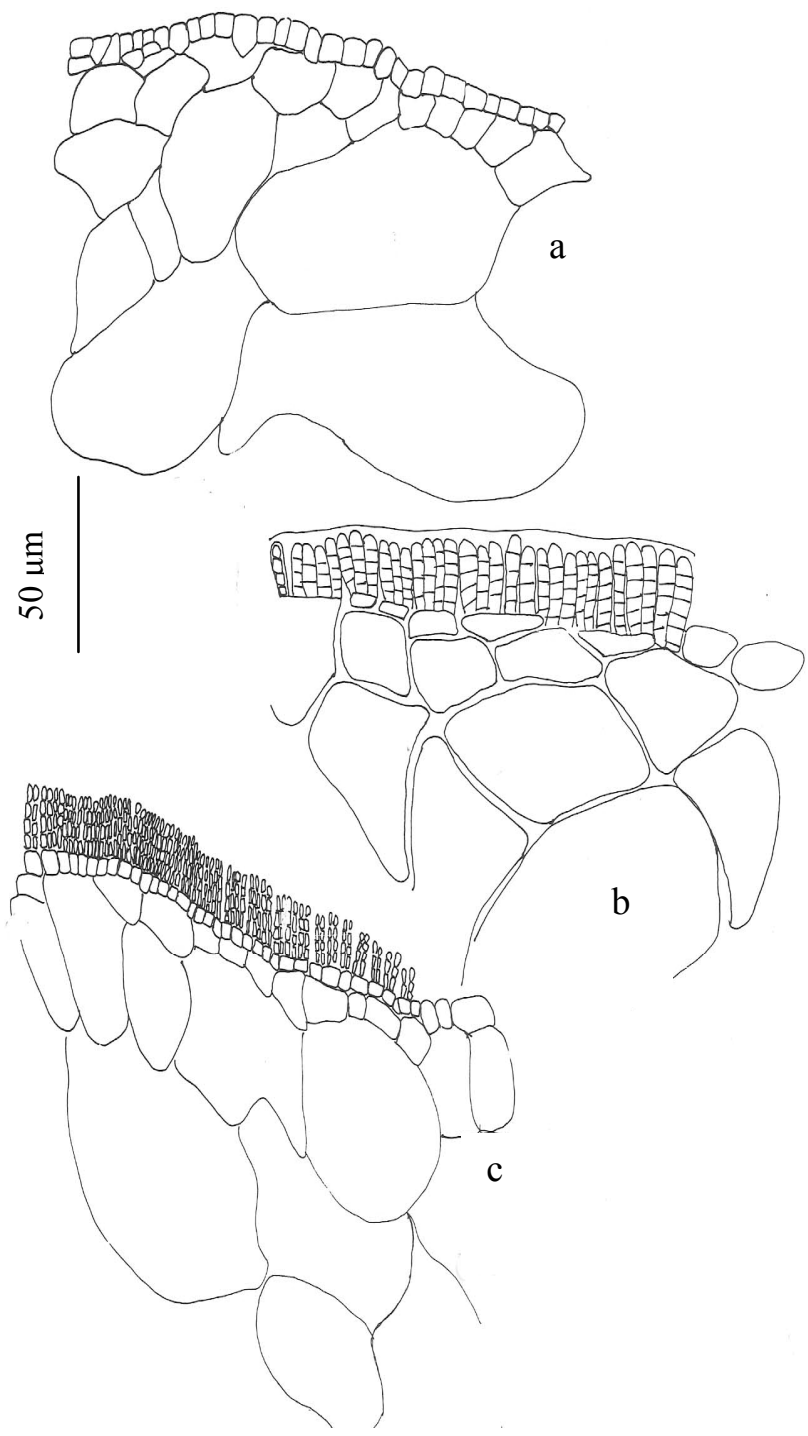

Fig. 2. Iyengaria lobocylindrica: $a$ - transverse section of the thallus; $b$ - transverse section showing uniseriate plurilocular sporangia; $c$ - transverse section of thallus with biseriate plurilocular sporangia

422 
Local distribution: Manora (Leg. Nizam. 5-2-1956, 6-12-1961, 20-1-1963, 21-11- \& 29-11-1964, Leg. Saifullah 17-12-1963, Leg. Qayum Akhter 17-031965, Leg. Farhana 16-12-1966, Leg. Rashida 23-03-1966, Leg. Nazrul Islam 20-11-1968, Leg. Aisha 11-11- \& 21-12-89); Buleji (Leg. Aisha 9-12-1989, 112-1990, 10-11- \& 14-11-1993).

Remarks. This species is distinguished by hollow projections, absence of phaeophycotean hairs and paraphyses, cortex not differentiated into inner and outer cortex, thin walled plurilocular sporangia with rectangular locules. It differs from Iyengaria stellata, the only so far known species, in thin walled thallus, undifferentiated cortex, hollow projections, plurilocular sporangia with rectangular locules, but resembles it in the shape of projections and absence of paraphyses. This new species has been named as Colpomenia lobocylindrica due to its peculiar thalli, which are lobed in early stages but gradually become cylindrical.

\section{Iyengaria stellata (Børgesen) Børgesen 1939:91 (Figs 3, 4, $a-c$ )}

Basionym: Rosenvingea stellata Børgesen 1928:1.

Synonyms: Colpomenia stellata (Børgesen) Børgesen 1930:168, Colpomenia capensis Levring 1938:20, Colpomenia sinuosa f. tuberculata (Saunders) Setchell et Gardner 1903:242 (misapplied name).

References: Børgesen 1930:168, 1934:26, 1939:91, Anand 1940:4, Fritsch 1952:111, Misra 1966:242, 1967:232, Krishnamurthy \& Joshi 1970:12, Nizamuddin \& Gessner 1970:6, Nizamuddin \& Begum 1978:316, Shameel 1987:513, 2000:52, Shameel \& Afaq-Husain 1987:295, Begum \& Khatoon 1988:31, 1992a:26, Shameel \& Tanaka 1992:40, Shameel et al. 1996:227, 2000:86, Silva et al. 1996:631, Alia \& Shameel 2010:3-22

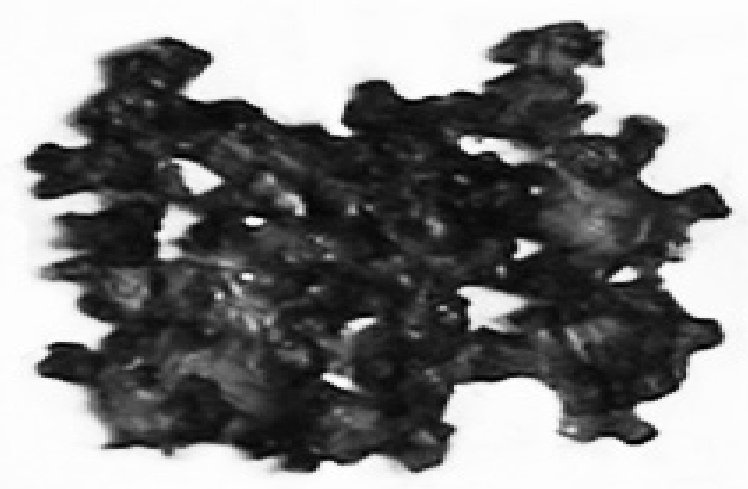

Fig. 3. Iyengaria stellata: Herbarium specimen

\section{Morphological characters}

Thallus light to dark brown, round to oval, up to $12 \mathrm{~cm}$ across; attached to the substratum by simple septate rhizoids; bearing many cylindrical projections up to $7 \mathrm{~mm}$ long, $4 \mathrm{~mm}$ broad; apices obtuse, di- or trichotomously branched, rarely polychotomous at the apex, solid at the young stage, becoming gradually hollow at maturity except near tips. 


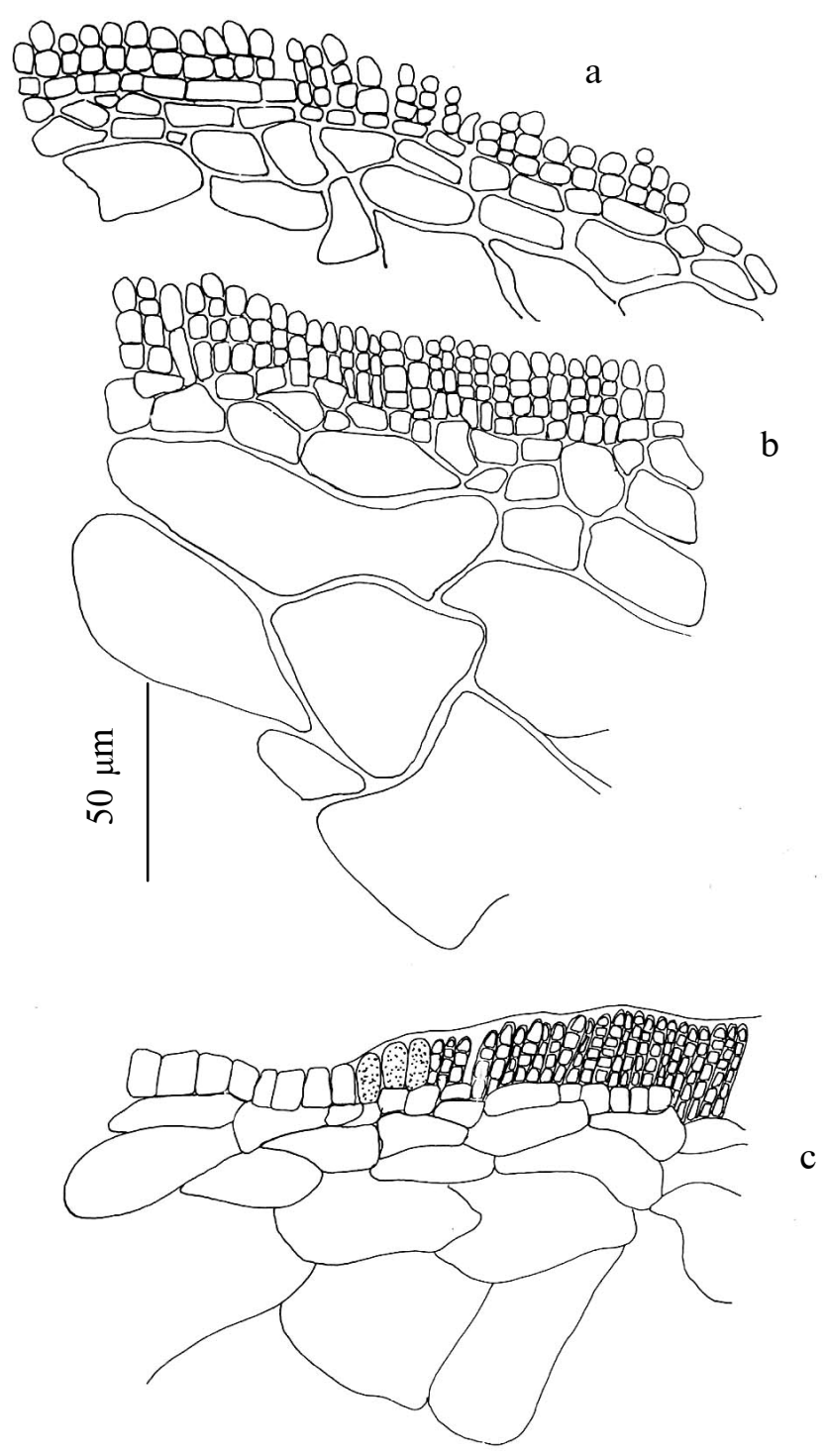

Fig. 4. Iyengaria stellata: $a$ - transverse section of thallus with plurilocular sporangia; $b$ - transverse section showing uniseriate plurilocular sporangia; $c$ - transverse section presenting paraphyses uniseriate plurilocular sporangia

\section{Cytological features}

Thallus composed of five to six or rarely more layers of cells, differentiated into peripheral \& cortical layers, and central cavity; single layer of peripheral cells squarish to rectangular, $6-10 \mu \mathrm{m}$ in length, $5-10(-25) \mu \mathrm{m}$ in breadth, radially arranged with dense phaeoplasts; cortex differentiated into outer and inner cortex, outer cortex two to three layers of small squarish to angular cells, 9-12 $\mu \mathrm{m}$ long, 13-23 $\mu \mathrm{m}$ broad, with a few phaeoplasts, inner 
cortex with large irregular cells, 31-34(-40) $\mu \mathrm{m}$ in length, (37-)53-77 $(-108) \mu \mathrm{m}$ in breadth; cell-wall up to $3 \mu \mathrm{m}$ thickened.

\section{Reproductive structures}

Sori scattered, containing plurilocular sporangia, 19-25 $\mu \mathrm{m}$ in length, 3-6(-27) $\mu \mathrm{m}$ in breath, enclosed in cuticle; sporangia mostly uniseriate, rarely biseriate, cylindrical, bearing 2-4 locules, rectangular; paraphyses absent, phaeophycotean hairs initially in deep cavities; unilocular sporangia lacking.

Growth: The growth is diffuse may be trichothallic in the part of phaeophycotean hairs.

Type locality: Dwarka, Gujarat, India.

Habitat ecology: It is epilithic, grows exposed to low tidal conditions on rocky platform in association with Dictyota bartayresiana Lamour. and Colpomenia sinuosa (Mertens ex Roth) Derbès et Solier.

Local distribution: Manora (Leg. Farida 11-10-1962, Leg. Shahida 28-121961, Leg. Naseem Ara 10-3-1965); Hawkesbay (Leg. Nizamuddin 11-101963, Leg. Qayum Akhter 02-3-1965, Leg. Nizamuddin 29-12-1966, Leg. Naheed Begum 24-1- \& 13-2-1970, Leg. Aisha 11-11-1989); Buleji (Leg. Nizamuddin 20-1-1963, Leg. Aisha 1-12- \& 29-12-1990, 6-2- \& 14-11-1993, 7-2-1994); Nathiagali (Leg. Aisha 16-10-1989); Cape Monze (Leg. Nizamuddin 21-11-1964).

Geographical distribution: California, India, Iran, Kuwait, Pakistan, Papua New Guinea, Saudi Arabia and South Africa.

Remarks. The species is characterised by the presence of solid projections in young stage which later on become hollow, absence of paraphyses in between the sori, phaeophycotean hairs in deeply sunken cavities, cortical cells thick walled, differentiated into outer and inner cortex. Specimens collected from Karachi coast resemble original description and the figure (Børgesen, 1939) but differ in irregular arrangement of cortical cells. It also completely agrees with the descriptions and diagrams of Misra (1966) Nizamuddin \& Begum (1978) except on maturity it becomes hollow. On the basis of above mentioned features it has been considered as Iyengaria stellata (Børgesen) Børgesen.

We are extremely grateful to Late Dr. M. Nizamuddin for permitting us to examine his large collection of herbarium of specimens and for his many valuable suggestions given during the course of study.

\section{REFERENCES}

Anand P.L., Marine Algae from Karachi. I. Chlorophyceae, Punjab Univ. Bot. Dep. Publ., Lahore, 1940.

Begum M. and Khatoon N., Pak. J. Bot., (20):291-304, 1988. 
Begum M. and Khatoon N., Pak. J. Bot., 24:22-30, 1992.

Børgesen, F., J. Ind. Bot. Soc., 9:151-174, 1930.

Børgesen F., Kgl. Danske Vidensk. Sels., Biol. Meddel, 19(1):1-85, 1934.

Børgesen F., Danish Scientific Investigation in Iran, Pt I, Copenhagen, pp. 47-143, 1939.

Fritsch F.E., Sturcture and Reproduction of the Algae, Vol. 2, Cambridge Univ. Press, Cambridge, 1952.

Krishnamurthy V. and Joshi H.V., A Check-List of Indian Marine Algae, Centr. Salt and Mar. Chem. Res. Inst., Bhavnagar, 1970.

Misra J.N., Phaeophyceae in India, Ind. Counc. Agricult. Res., New Dehli, 1966.

Misra J.N., Proceeding of the Seminar on Sea, Salt and Plants, Bhannagar, pp. 227-233, 1967.

Nizamuddin M. and Gessner F., Meteor Forsch. Ergeb., Ser. D, 6:1-44, 1970.

Nizamuddin M. and Begum N., Rev. Algol. N. S., 2(13):315-326, 1978.

Shameel M., Pak. J. Mar. Biol., 7:233-250, 2001.

Shameel M., Int. J. Phycol. Phycochem., 4:225-232, 2008.

Shameel M., Bot. Mar., 30:511-515, 1987.

Shameel M., Proceeding of National O.N.R. Symposium on Arabian Asea as a source of Biological Diversity, H.E.J. Res. Inst. Chem. Univ. Karachi, pp. 45-64, 2000.

Shameel M. and Afaq-Husain S., Modern Trends of Plant Science Research in Pakistan, Proc. Nat. Conf. Plant Sci., Peshawar, pp. 292-299, 1987.

Shameel M. and Tanaka J., Cryptogamic Flora of Pakistan, Vol. 1, Natl. Sci. Mus., Tokyo, pp. 1-64, 1992.

Shameel M., Aisha K., and Khan S.H., Bot. Mar., 39:223-230, 1996.

Shameel M. Khan S.H., and Afaq-Husain S., Pak. J. Mar. Sci., 6:69-100, 2000

Silva P.C., Basson W., and Moe R.L., Catalogue of the Benthic Marine Algae of the Indian Ocean, Univ. California Press, Berkeley, 1996.

Received 21.01.2014

Submitted by S.P. Wasser

\section{ISSN 0868-854 (Print)}

ISSN 2413-5984 (Online). Algologia. 2015, 25(4):420-427

http://dx.doi.org/10.15407/alg25.04.420

\section{К. Айиша, М. Шамиль}

Кафедра ботаники, Университет Карачи, Карачи-75270, Пакистан

НОВЫЙ ВИД РОДА IYЕNGARIA ВØRGESEN (РНАEOРНYСОТА) ИЗ ПРИБРЕЖНЫХ ВОД КАРАЧИ (ПАКИСТАН)

Представлены результаты таксономического исследования представителей бурых водорослей рода Iyengaria, шаровидные, полые и звездообразные талломы которых были отобраны из различных прибрежных зон Карачи. Как показало исследование, 
талломы относятся к двум видам этого рода: I. stellata (Bшrgesen) Bшrgesen и новому виду I. lobocylindrica Aisha et Shameel. Отличительные признаки нового вида тонкостенный таллом, полые выступы, кора не дифференцирована на внутреннюю и внешнюю, волоски отсутствуют, спорангии тонкостенные, многокамерные с прямоугольными ячейками. Молодые стадии имеют лопастное строение, но постепенно талломы становятся цилиндрическими.

Ключевые слова: algae, Phaeophycota, Iyengaria, таксономия, морфология, анатомия, воспроизведение.

\section{Новые книги}

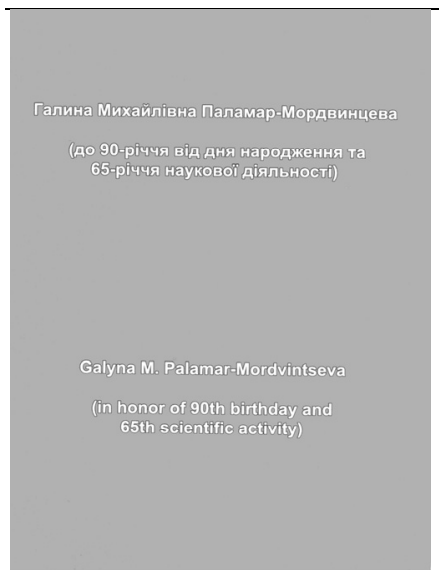

Галина Михайлівна Паламар-Мордвинцева: до 90-річчя від дня народження та 65-річчя наукової діяльності / Царенко П.М., Паламар-Мордвинцева Г.М., Вассер С.П., Виноградова О.М. - К., Інститут ботаніки ім. М.Г. Холодного НАН України, 2014. - 78 с.

У книзі висвітлені життєвий шлях, наукова та педагогічна діяльність відомого українського фіколога, доктора біологічних наук, професора Г.М. ПаламарМордвинцевої, а також вітальні звернення колег та особисті спогади й роздуми ювіляра щодо пережитих подій та окремих особистостей. Представлений хронологічний показник публікацій, що ознайомлює читача 3 творчим доробком вченого.

Книга розрахована на спеціалістів у галузі ботаніки, історії ботанічної науки, викладачів, аспірантів, студентів.

The book covers life path, scientific and pedagogical activity of the famous Ukrainian phycologist Prof. Galyna M. Palamar-Mordvintseva. The book also contains personal memories and reflections of the on experienced events and some individuals. Chronological list of the publications is given.

This book is designed for the specialists in the area of botany and its history, for the teachers and students. 